https://nv.nltu.edu.ua

https://doi.org/10.36930/40290804

Article received 23.09.2019 p.

Article accepted 31.10.2019 p.

ISSN 2519-2477 (online)

УДК 550.34:621.039.58

$@ \bowtie$ Correspondence author

A. P. Havrys

havrys.and@gmail.com

А. П. Гаврись, Р. Я. Моренюк, І. М. Гарасимюк

Львівський державний університет безпеки життєдіяльності, м. Львів, Україна

\title{
МЕТОД ПРОСТОРОВОГО РОЗМІЩЕННЯ ПОЖЕЖОНЕБЕЗПЕЧНИХ ДІЛЯНОК НА ПІДСТАВІ ДАНИХ ДИСТАНЦЙНОГО ЗОНДУВАННЯ ЗЕМЛІ
}

\begin{abstract}
Проаналізовано дані дистанційного зондування Землі зі супутника MODIS, на яких відображається інфрачервоний спектр температур у вигляді точок (загорянь) на території Австралії. Встановлено, що ці дані являють собою пікселі, що показують температури вище порогового значення, а не окремі пожежі. Проведено моделювання ділянок пожеж використовуючи точки загорянь 3 подальшим відображенням на картах пожежонебезпечних місць. Встановлено та проаналізовано графічну залежність між кількістю кластерів та відстанню між точками в окремих кластерах. Визначено оптимальну відстань для класифікації скупчення точок як однієї пожежі та створення полігону пожежонебезпечного місця за допомогою інструментів програми ArcGIS. Проведено моделювання відображення наслідків пожеж з використанням історичних зображень Землі, на прикладі Австралії в період із грудня 2012 по грудень 2013 рр. Проведено моделювання зміни температури загорянь у різних точках. Створено і проаналізовано карти впливу пожеж та карти пожежної небезпеки для органів місцевого самоврядування на прикладі територій Австралії. Створено карти гарячих точок з використанням кластерного аналізу для визначення просторової зміни температури загоряння в цих точках. Запропоновано використовувати наведений метод локалізації пожежонебезпечних ділянок разом з історичними даними про пожежі обраного регіону для прогнозування й аналізу ймовірності виникнення загорянь на окремих досліджуваних територіях.
\end{abstract}

Ключові слова: комп'ютерне моделювання; загоряння; супутникові дані; лісова пожежа; кластерний аналіз.

Вступ. Лісові пожежі є великою проблемою як в Україні, так і далеко за ії межами. Щороку шкоди зазнають тисячі людей по всьому світу. Великий негативний вплив позначається на екосистемах, а люди зазнають як фізичних втрат (опіки, травми, смерть), так і значних матеріальних втрат. Тому необхідним $є$ завчасне попередження та моніторинг виникнення таких пожеж. Сьогодні ми можемо здійснювати таку профілактику виникнення пожеж за допомогою сучасних технологій та обмінюючись міжнародним досвідом, отримувати нові корисні знання для запобігання такого роду надзвичайним ситуаціям.

Щодня із супутників отримують інформацію для оперативного дистанційного моніторингу лісових пожеж. Моніторинг лісових пожеж дає змогу ліквідовувати їх на ранніх стадіях. Сучасні ГІС-технології дають змогу отримувати інформацію з усього земного шару та навіть 3 космосу (Starodub et al., 2013; Starodub \& Havrys, 2015a, 2015b; Havrys, Steciuh \& Romanchuk, 2018; Zatserkovnyi, Tishayev \& Shyshenko, 2016).

Працівники Державної служби з надзвичайних ситуацій щороку проводять спеціальні заходи, спрямовані на збереження довкілля, перед початком пожежонебезпечного періоду (Havrys, 2018). Розробляють і затвер- джують оперативно-мобілізаційні плани щодо дій підрозділів у разі виникнення лісових пожеж. Держлісгоспи прокладають мінералізовані смуги та протипожежні розриви, а також здійснюють догляд за прокладеними раніше смугами і розривами. Для чіткої і правильної взаємодії підрозділів ДСНС та Мінлісгоспу ці органи керуються наказом № 89/132 від 12.03.2007 "Про затвердження Інструкції про порядок взаємодії підрозділів відомчої пожежної охорони Держкомлісгоспу України i пожежно-рятувальних підрозділів Оперативно-рятувальної служби цивільного захисту МНС України під час гасіння лісових пожеж".

Лісові господарства вживають всі необхідні можливі заходи для зниження ризику виникнення лісових пожеж. Від початку 2019 р. в українських лісах було встановлено 115 км протипожежних розривів та 8,1 тис. км мінералізованих смуг, проведено догляд за ними в обсязі 17,7 тис. км, перекрито 9,5 тис. позапланових доріг. Уздовж доріг лісових масивів і в місцях відпочинку людей вже встановлено 7,8 тис. аншлагів, панно, плакатів на протипожежну тематику (Recourses Agency, 2019). Проте цих заходів недостатньо, оскільки час виявлення та локалізації пожежонебезпечних ділянок залишається великим, що спричиняє великомасштабні лісові пожежі.

Інформація про авторів:

Гаврись Андрій Петрович, канд. техн. наук, викладач, кафедра цивільного захисту та комп'ютерного моделювання екогеофізичних процесів. Email: havrys.and@gmail.com; https://orcid.org/0000-0003-2527-7906

Моренюк Роксолана Ярославівна, магістрантка, кафедри цивільного захисту та комп'ютерного моделювання екогеофізичних процесів. Email: morenyuk@ukr.net

Гарасимюк Іван Михайлович, магістрант, кафедри цивільного захисту та комп'ютерного моделювання екогеофізичних процесів. Email: ivan.garasymyuk@gmail.com

Цитування за ДСту: Гаврись А. П., Моренюк Р. Я., Гарасимюк І. М. Метод просторового розміщення пожежонебезпечних ділянок на підставі даних дистанційного зондування землі. Науковий вісник НлтУ України. 2019, т. 29, № 8. С. $36-42$.

Citation APA: Havrys, A. P., Moreniuk, R. Ya., \& Harasymiuk, I. M. (2019). Method of fire areas localization on the basis of remote sensing data. Scientific Bulletin of UNFU, 29(8), 36-42. https://doi.org/10.36930/40290804 
Проблема виникнення та локалізації лісових пожеж поширена також далеко за кордонами нашої держави. Щороку від лісових пожеж потерпає Австралія, оскільки там сухий клімат та високі температури, котрі сприяють виникненню пожеж. Так, у 2009 р. на початку лютого у штаті Вікторія сталися великі лісові пожежі, котрі призвели до смерті більше 180 людей. Було завдано значних матеріальних втрат, люди втратили близько 750 будинків. Тоді було зафіксовано найвищу температуру за останні 150 років.

Великі пожежі були в Австралії також у 2013 р., тоді в Новому Південному Уельсі було оголошено надзвичайний стан. Більше 35000 га землі постраждало від вогню, кілька сотень будинків було зруйновано. У місті Хобарта температура повітря сягала рекордної позначки $+42{ }^{\circ} \mathrm{C}$. Австралія щоліта потерпає від лісових пожеж, причинами котрих $є$ посушливий клімат та антропогенний вплив, а саме необережне поводження з вогнем (Test center, 2019).

Для зменшення збитків від виникнення лісових пожеж, вчасного моніторингу та прогнозування наслідків доцільно використовувати дані, отримані за допомогою дистанційного зондування Землі, що охоплюють великі площі досліджуваної території. Один із методів локалізації пожежонебезпечних ділянок (на прикладі Австра- лії) на основі даних дистанційного зондування Землі представлено в цій роботі.

Мета дослідження - розробити метод просторового розміщення пожежонебезпечних ділянок на основі даних дистанційного зондування Землі за допомогою програмного забезпечення ArcGIS.

Об'єкт дослідження - процес раннього виявлення та прогнозування наслідків надзвичайних ситуацій, що виникають у навколишньому природному середовищі, де існують загрози життю та здоров'ю людей.

Предмет дослідження - вплив надзвичайних ситуацій природного характеру на навколишнє природне середовище та людей, що в ньому проживають.

Точки пожеж та кластери пожеж. Використані дані в цьому розділі стосуються лісових пожеж в Австралії у січні 2013 р., отримані від Служби інформації спостереження Землі (The NASA Earth Observation System Data Information Service (EOSDIS)). Ця служба EOSDIS забезпечує моніторинг глобальних пожеж у режимі реального часу, а також зберігає дані в архівах. Можна використовувати різні статистичні підходи, а також визначити та перевірити шаблони кластеризації в даних. Походження вхідних даних для запропонованого методу наведено в таблиці.

Таблиця. Інформаційні джерела вхідних даних для запропонованого методу

\begin{tabular}{|c|l|}
\hline Шари (Layer) & \multicolumn{1}{|c|}{ Опис } \\
\hline $\begin{array}{c}\text { Лісові пожежі в січні } \\
2013 \text { p. } \\
\text { (wildfire_jan2013) }\end{array}$ & "Точки пожеж". Клас особливостей даних точок лісових пожеж за період з 1 січня по 29 січня \\
& $\begin{array}{l}\text { (NASA, 2019). } \\
\text { Документ EODIS_wildfire_shapefile.pdf надає метадані для цього набору даних). }\end{array}$ \\
\hline Полігони (Land) & Полігони Австралійських земель (завантажено 3 Natural Earth (Natural Earth, 2019) 1:50 m) \\
\hline Штати (States) & Штати Австралії (завантажено з Natural Earth 1:50 m) \\
\hline Міські території (Urban) & Полігони міських територій (завантажено з Natural Earth 1:50 m) \\
\hline Місця (Places) & Точки населених пунктів (завантажено з Natural Earth 1:50 m) \\
\hline
\end{tabular}

Завантажуємо шари даних лісових пожеж до нової карти в середовищі ArcGIS та проводимо їх короткий огляд.

Більшу увагу варто звернути на:

1. Розподіл точок на континентальному та місцевому масштабах.

2. Географічні зміни температури пожеж (ї яскравість).

Ці точки є центроїдами віддалених пікселів, зображені $з$ орієнтовною роздільною здатністю $1 \mathrm{kм}^{2}$, отримані впродовж кількох супутникових спостережень. Точки мають достатньо високу яскравість, щоб вважатися вогнем, і не відповідають відомому природному або антропогенному джерелу (рис. 1).

Проаналізувавши додані шари, бачимо, що точки пожеж трапляються на більшій частині континенту, за винятком частини Південної Австралії та південно-західної Австралії. Багато точок, здається, згруповані у глобулярні (сферичні чи кульові) скупчення, але трапляються і деякі вільні лінійні скупчення (кластери), їх можна краще побачити у збільшеному масштабі. Такі лінійні скупчення вогневих точок, наприклад, можна побачити на центрально-східному узбережжі Квінсленда.

Існують певні ознаки того, що точки пожеж досягають більших температур у центральних районах, ніж у прибережних. У разі збільшення масштабу окремі сферичні скупчення стають чіткішими і з часом з'являються як роз'єднані скупчення точок, розділених між собою (рис. 2).

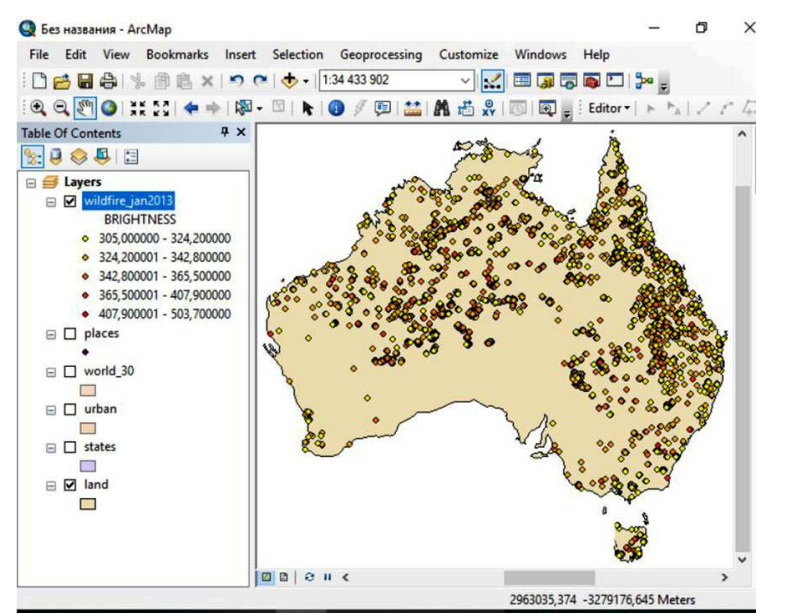

Рис. 1. Географічний розподіл точок пожеж та їх температур у програмному середовищі ArcGIS

Точки з котрих утворюються ці скупчення, розміщені значно ближче один до одного, ніж самі скупчення (кластери). Це кластери, котрі перетворюються в так звані полігони (багатокутники) слідів пожеж.

Тепер розуміємо, що дані та структура даних, тобто їх формат (точки пожеж), поля (яскравість - температура $є$ однією $з$ найважливіших), а також географічний розподіл точок пожеж і їх температури. Проаналізувавши додані шари розуміємо, що точки являють собою місця пожеж, а не індивідуальні пожежі. Індивідуальні пожежі є скупченнями багатьох точок. 


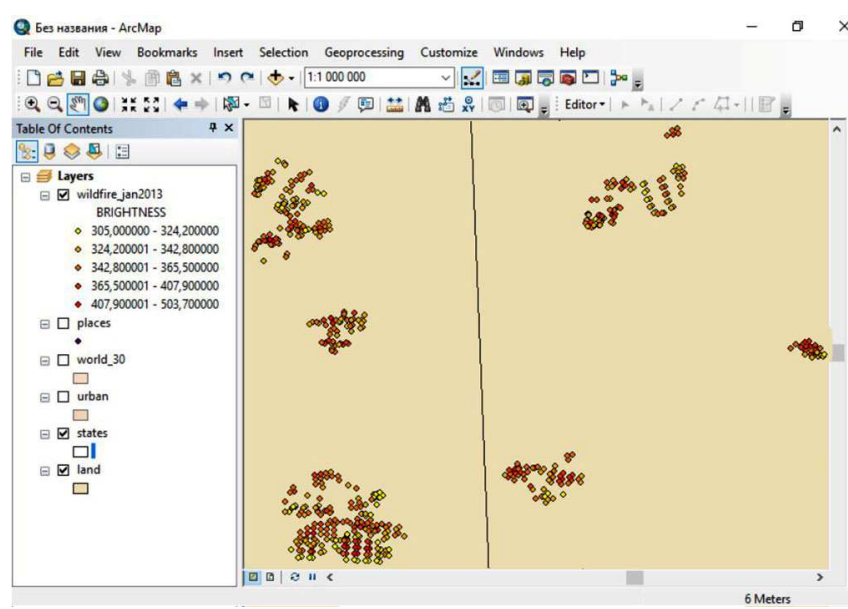

Рис. 2. Збільшений масштаб окремих сферичних скупчень (вогневих точок) у програмному середовищі ArcGIS

"Індивідуальні пожежі" - це сукупності багатьох точок, причому кількість точок визначається:

- індивідуальним розміром пожежі - більші пожежі мають більше точок у сукупності.

- тривалістю кожної пожежі - довші пожежі фіксуються більшою кількістю супутникових спостережень.

- частотою супутникових спостережень (більше спостережень - більше точок).

- іншими чинниками, такими як хмарність і несправність чи неточність техніки в ході спостереження.

Усі ці точки пожеж є взаємозалежними. Якщо моделюємо "індивідуальні пожежі" з точок пожеж, то спостереження тепер незалежні один від одного (один запис для кожної пожежі) і незалежні від можливих внутрішніх пожеж.

Щоб створити незалежні полігони місць пожеж, потрібно:

1. Групувати точки в кластери на основі просторової близькості.

2. Створити полігон слідів пожеж навколо кожного кластера.

Використовуючи інструмент "Measure" програми ArcGIS, знаходимо відстань між видимими кластерами по всій Австралії, як показано на рис. 3.

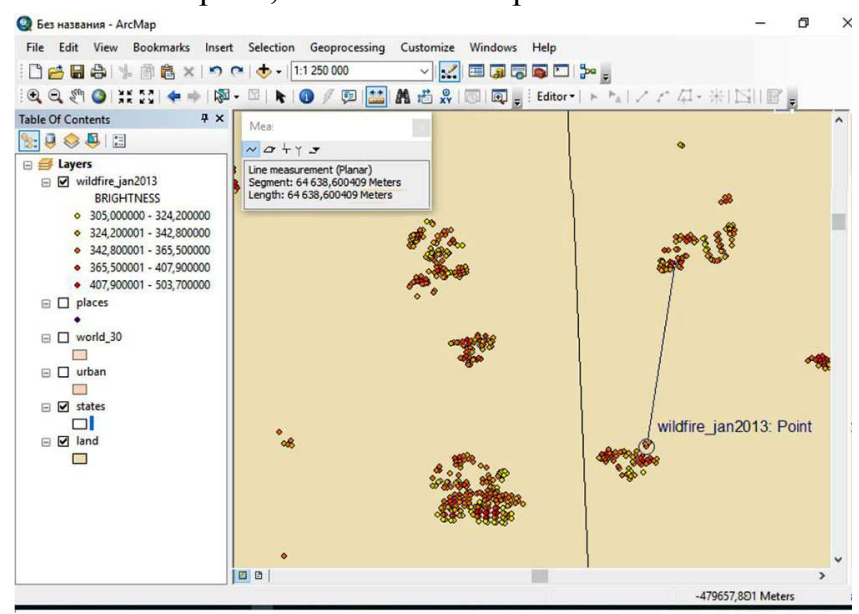

Рис. 3. Використання інструменту "Measure" програми ArcGIS у програмному середовищі ArcGIS

Існує велика різниця у відстані між парою кластерів, котрі майже доторкаються один до одного, і між тими, що розділені більш ніж на 100 км, але здебільшого одні кластери явно не перетинаються 3 сусідніми. $€$ такі кластери, відстань між котрими досить невелика, звідси важко визначити це є один кластер чи декілька окремих кластерів.

Якщо поділити полігони навколо кожного візуального кластера, то вони повинні відрізнятись якимись явними ознаками. Це може зайняти досить багато часу, оскільки існує близько 22000 точок в одному кластері. Було б набагато простіше, якщо такі кластери можна було б ідентифікувати автоматично.

Один простий кластерний підхід полягає в тому, щоб виміряти відстань між усіма парами точок, а потім між парами невеликих кластерів, котрі знаходяться недалеко один від одного. На рис. 4 точки всередині кожного кластера розміщені в межах однієї одиниці принаймні однієї іншої точки в кластері, тоді як найближчі точки в різних кластерах знаходяться на двох одиницях. Отже, порогове значення кластеризації групує точки на дві множини, в яких всі точки всередині множини знаходяться в межах однієї одиниці іншої точки набору.

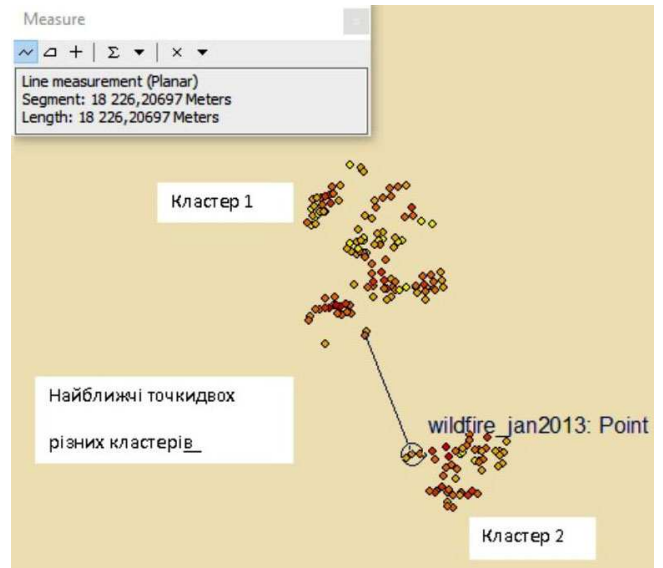

Рис. 4. Зображення найближчих точок між двома різними кластерами у програмному середовищі ArcGIS

Для вибору оптимального порогового значення потрібно врахувати, як кластеризація змінюється залежно від відстані кластерів. Розглянемо рис. 5, низький поріг відстані до 0,5 означає, що ця ділянка може бути поділена на три кластери, тоді як більша відстань 1 одиниця призводить до поділу лише на два кластери. Коли відстань достатньо велика для подолання розриву між кластерами (2,5 одиниці), всі точки цієї групи знаходяться в межах одного кластера.

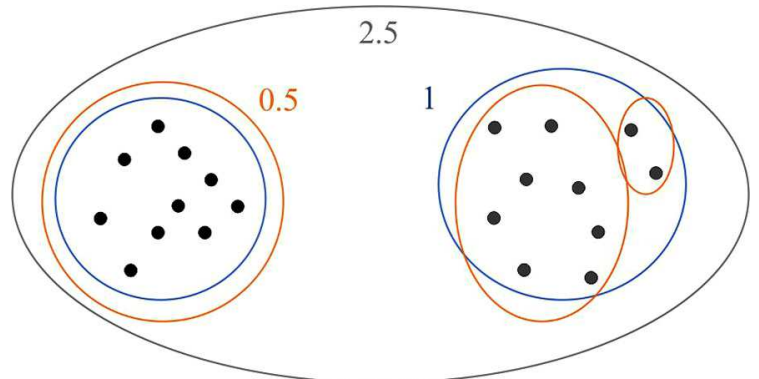

Рис. 5. Схематичне зображенння кластеризації точок

Кількість кластерів зменшується, а порогова відстань збільшується, але це співвідношення залежить від масштабу, за якого відбувається поділ на групи (кластеризація). У нашому прикладі збільшення 3 порогового значення від 0,5 до 1 зменшує кількість кластерів 33 до 2 , але додаткові 0,5 кроків не призводять до зменшення кількості кластерів до досягнення 2,5. Нові кластери не ідентифікуються між 1 і 2, тому кластеризація відбувається в масштабі 1 одиниці. 
Тепер розглянемо дані пожежі. Якщо побудувати кількість кластерів точок пожеж 3 пороговою відстанню, то можна кількісно визначити співвідношення між кластеризацією та масштабом. Інструментом "Aggregate Points (Cartography)" робимо кластеризацію, щоб визначити оптимальну порогову відстань. Використовуючи інструмент "Aggregate Points (Cartography)", генеруємо полігони навколо кожного кластера.

Для створення кластерів на порогових відстанях 1, $2,3,5,7,10,15,20$ і 30 км використовуємо інструмент "Aggregate Points (Cartography)" дев'ять разів. Називаємо їx "fire_cluster_xkm", замінивши х на відстань. Далі використовуємо інструмент "Get Count" для підрахунку кількості повернених кластерів для кожного порогу.

Зобразимо графічно залежність кількості кластерів від відстані у програмі Microsoft Excel (рис. 6).

Спочатку кількість кластерів зменшується дуже швидко зі збільшенням відстані, але цей спад поступово сплющується до майже лінійного на пороговій відстані 7 км. Нахил графіка свідчить про відстань кластеризації близько 7 км.

У програмі ArcМap порівнюємо візуально полігони місць пожеж, що з'являються в кожній з цих ділянок (рис. 7).

Графік запропонував відстань кластера приблизно 7 км порогової відстані (у масштабі). У наведеному вище прикладі масштаби, менші за 5 км, призводять до витягнутих і непересічних (більше ніж одного) полігонів у видимих кластерах. На відстані 5 км візуальні скупчення досить неправильної форми, але на 7-кілометровому масштабі генеруються у вигляді територій правильної округлої форми, котрі збігаються із дійсними контурами пожежонебезпечних ділянок (Starodub et al., 2013). Більші відстані утворюють полігони правильної форми. Надалі порівнюємо різні кластери пожеж 3 історичними зображеннями 3 Google Earth (Google Earth, 2019), щоб побачити, наскільки добре кластери відповідають видимим місцям пожеж.

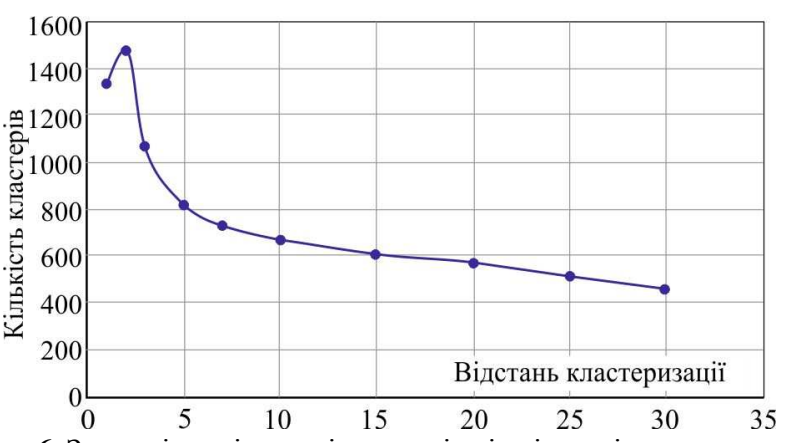

Рис. 6. Залежність кількості кластерів від відстані кластеризації (км)

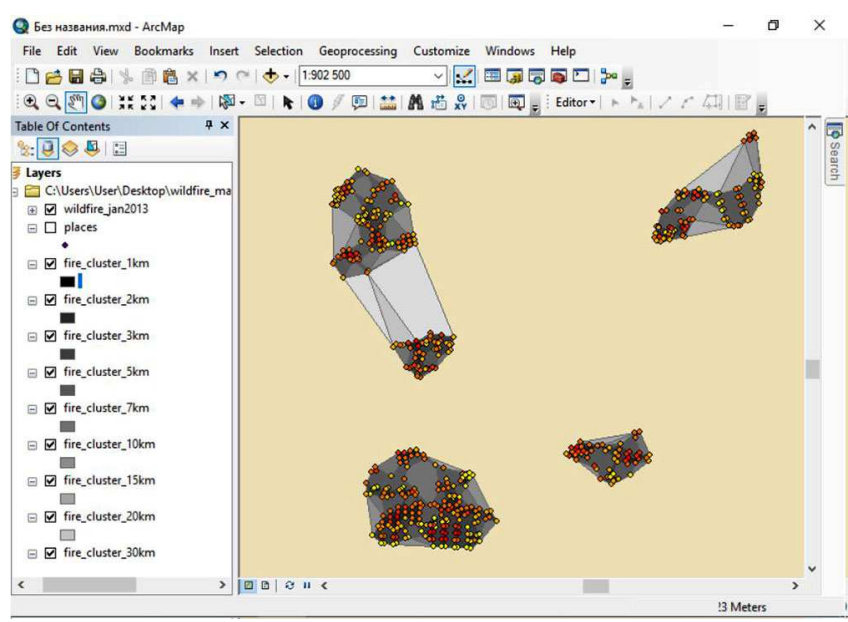

Рис. 7. Полігони пожежонебезпечних місць у програмному середовищі ArcGIS

За допомогою використання інструменту "Layer to KML" експортуємо точки пожеж і полігони місць пожеж, створених 3 пороговими значеннями відстані 5, 7 і 10 км. Відкриваємо програму Google Earth, а потім додаємо наші KML файли. Збільшуємо область із кластерами пожеж та активуємо повзунок історичних зображень ("View > Historical Imagery"). Використовуємо повзунок для порівняння останнього зображення, перш ніж пожежа сталася 3 першим зображенням після пожежі.

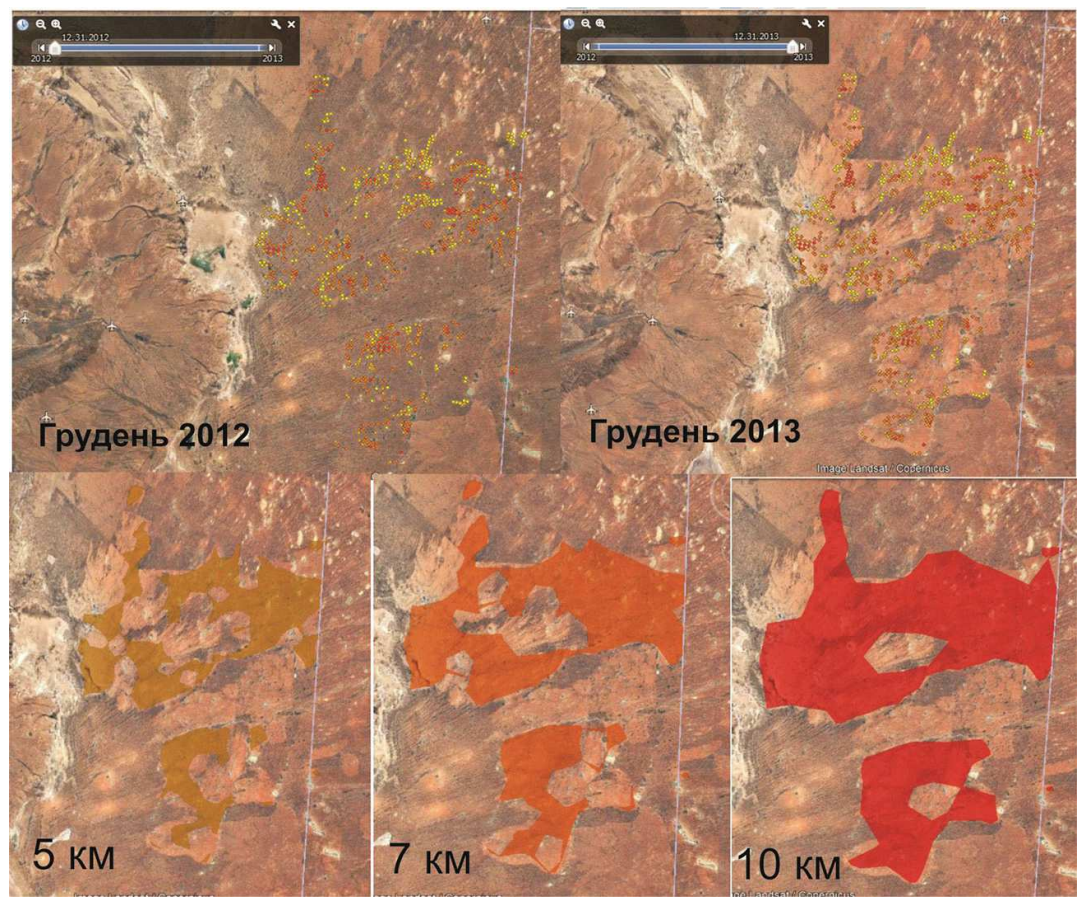

Рис. 8. Кластери пожеж у пустелі Австралії в період з грудня 2012 р. по грудень 2013 р. 3 використанням платформи Google Earth 


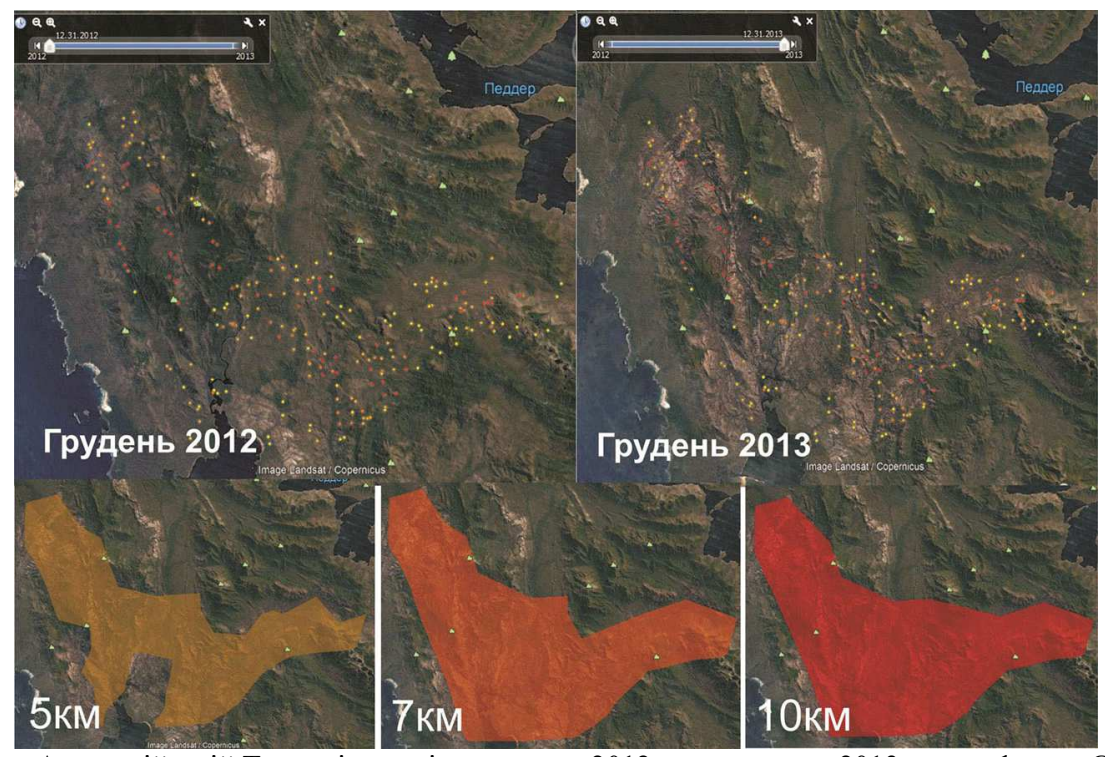

Рис. 9. Кластери пожеж в Австралійській Тасманії в період з грудня 2012 р. по грудень 2013 р. платформи Google Earth

Докази того, що зміни відбулися, помітні на багатьох кластерах ділянок пожеж. На рис. 8 та 9 наведено два приклади: перший - пустельне розташування в континентальному просторі, другий - лісиста територія Тасманії, де переважає помірний клімат.

У пустелі сліди пожеж добре видно, як світліші ділянки. У цьому прикладі є ділянки місць пожеж, де не показано пожежі, що повинні бути в період з лютого по грудень 2013 р. Оскільки існують місця пожеж, котрі пов'язані між собою. Тому важко оцінити відповідність між спостережуваними і модельованими місцями пожеж.

Другий приклад - лісова пожежа в Тасманії, котра була єдиною ізольованою пожежею в період 34 по 7 січня. Наслідки цієї пожежі видно на рис. 9, як світліші ділянки, що є результатом втрати рослинності. $€$ свідчення про пожежі на півдні, де зображено точки пожеж, 5-кілометровий кластер, що має підковоподібний вигляд, зображення котрого стає чіткішим за більшої відстані. 7-кілометровий поріг, таким чином, здається найбільш прийнятним для цього кластера.

Отже, можна зробити обгрунтований вибір оптимального поділу на кластери за пороговою відстанню.

1. Точки пожеж - це центроїди приблизно 1 км² пікселів, i отже, поріг повинен бути більше 1 км для точок кластера, захоплених одночасно.

2. Групові пожежі можуть бути до 20 км, тому це максимально реалістичний поріг (The Kilmore East Fire, 2010).

3. Поділ на кластери зменшується над пороговою відстанню приблизно 7 км, як це видно з графіка.

4. Поріг у 7 кілометрів має найкращий візуальний збіг 3 Google Imagery для прикладу пожеж в Тасманії (Tasmania, 2019) та ін. Враховуючи наведену вище інформацію, будемо використовувати порогову відстань у 7 км.

Точкова карта впливу небезпек. Поле "Bright_T31" точок пожеж зберігає температуру поверхні, отриману з "31 каналу", але ця інформація була втрачена в процесі об'єднання точок пожеж у полігони. Точки пожежі в межах місця слідів пожежі - це зразок температури вогню в цьому місці пожежі. Оцінимо температуру кожного місця пожежі, обчисливши середне значення точок, що складають кожен полігон місця пожежі. Просторово приєднуємо точки пожежі до полігонів місць пожежі "fire_cluster_7km" і розраховуємо кількість, середнє та стандартне відхилення "Bright_31" для кожної ділянки пожежі. Називаємо вихідний шар "fire_cluster_7km_bright".

Австралія дуже велика порівняно з розміром слідів пожеж, тому перегляд таких місць пожеж як полігону в континентальному масштабі не $\epsilon$ практичним. Враховуючи велику різницю в масштабах між полігонами і континентом, краще моделювати місця пожеж як точки, а не полігони.

Перетворення в точки має три переваги:

1. Усі місця пожеж відображаються однаково незалежно від розміру (символи точок можуть бути визначені за площею полігону).

2. Полігони потребують більшого запам'ятовування, а це означає, що все відбувається повільніше, включаючи час коли зображення з'являється на екрані.

3. Точки - це формат просторових даних, необхідний для деяких інших аналітичних інструментів, які будуть використовуватися надалі.

Використовуємо інструмент "Feature to Point" для перетворення полігонів у точки. Називаємо файл "fire_cluster_7km_bright_pt".

Опис просторового розподілення температури на ділянці пожежі наведено на рис. 10.

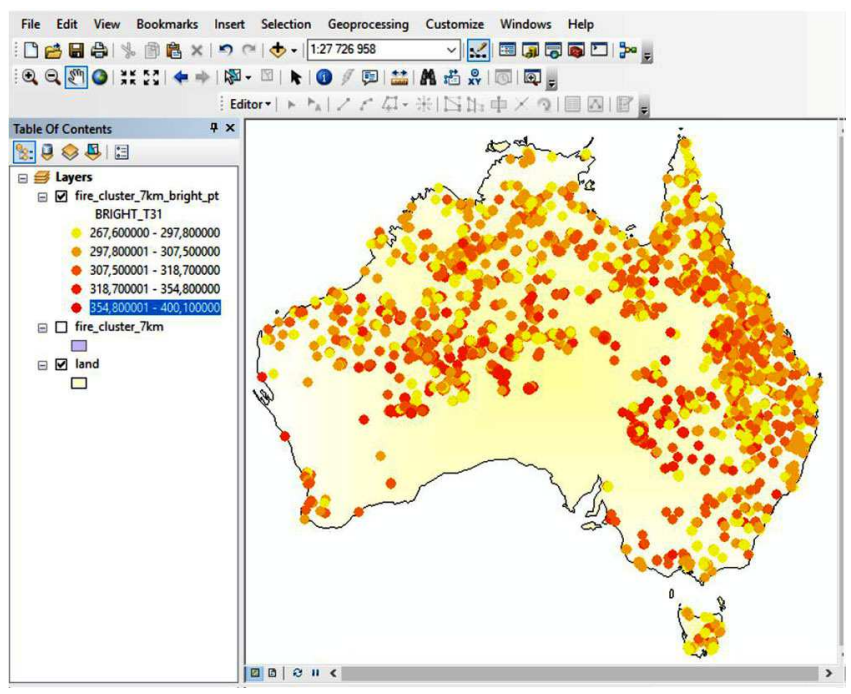

Рис. 10. Просторове розподілення температури на ділянках пожеж у програмному середовищі ArcGIS

Спростивши дані та усунувши варіанти в межах пожеж, щоб можна було бачити й аналізувати відмінності 
між місцями пожеж на регіональному масштабі, без додаткової складності варіацій у пожежах. Це було зроблено, оскільки значні коливання температур пожеж залишаються очевидними по всьому континенту і частіше трапляються у центральних регіонах, ніж у бік узбережжя. Австралійський клімат посушливий, а на півночі вологий. Пожежі досягають високих температур, коли температура повітря висока і вологість низька, тоді як пожежі у лісах де вологість вища трапляються рідше, і тому там прохолодніше.

Мета карти впливу небезпеки полягає в тому, щоб показати, де виникла небезпека і якою мірою. Карта зі зображенням точок пожеж дає повний огляд виникнення лісових пожеж на материку у січні 2013 р., але точки, що знаходяться близько, закривають одні одних, затуляючи рисунок.

Іншим недоліком точкових карт є те, що інформація про пожежі безпосередньо не пов'язана 3 іншою інформацією, наприклад, розподіл ресурсів часто здійснюється через регіональні органи влади, тому існує потреба знати, який вплив відбувається в межах політичних або інших адміністративних одиниць.

Створення карт гарячих точок. Візуальний огляд температур місць пожеж свідчить про те, що вони не $є$ просторово випадковими, оскільки пожежі з високими температурами можуть бути більш поширеними в центральних регіонах, ніж у північних і східних узбережжях. Для того, щоб визначити реальність зображуваних температурних даних можна використати такі підходи:

1. Класифікувати місця пожеж як у центральних районах, так і за їх межами, побудувавши зміну температури в межах цих двох класів як приклад, а потім скористатися t-критерієм, щоб перевірити, чи відрізняється температура пожеж у центрі материка від інших.

2. Виміряти відстань кожного місця пожежі до узбережжя і визначити найвищу температуру на відстані, після чого використати регресійні моделі для пошуку відповідного співвідношення.

3. Зіставити просторову поліноміальну поверхню до температури місця пожежі.

4. Використати кластерний аналіз для виявлення значних просторових кластерів місць пожеж 3 високими або низькими температурами.

Проте найефективніший з точки зору аналізу є четвертий підхід. Отже, проаналізуємо гарячі точки пожеж. У теорії потрібно визначити чи "гарячі" та "прохолодні" пожежі скупчуються географічно.

Практично, використаємо інструмент "Hot Spot Analysis", який обчислює статистику Getis-OrdGi, яка перевіряє функцію кластерів у просторі з іншими функціями $з$ подібними високими та низькими значеннями (ArcGIS Pro, 2019). ArcGIS має два інструменти для аналізу гарячих точок - оптимізований інструмент для аналізу гарячих точок, який автоматично оптимізує параметри функції, зокрема, модель просторових відносин як смуги відстаней (сфери впливу) та інструмент "Hot Spot Analysis", який забезпечує більший контроль за параметрами аналізу.

Запускаємо інструмент "Optimized Hot Spot Analysis" на шарі "fire_cluster_7km_bright_pt" із полем "bright31_mean" як "Anälysis Fiēld".

Перш ніж інтерпретувати вихідне зображення, потрібно знати, який оптимізований діапазон відстані (сфери впливу) існує, оскільки це відстань відключення, в межах якої використовуються характеристики в розрахунках. Відкриваємо вікно "Geoprocessing > Results", а потім відкриваємо розділ повідомлень оптимізованого аналізу "Hot Spot". Тут інструмент записує інформацію про свою роботу.

Розділ "Scale of Analysis" повідомляє, що оптимальна відстань не була визначена на основі інтенсивності кластеризації, тому замість цього була використана середня відстань до 30 найближчих інших точок. Використовуваний поділ відстані трохи менше 300 км, тому кожна пожежа оцінюється як істотний кластер $з$ різною високою або низькою температурою в межах 300 км від цієї поділки. Це означає, що автоматично визначена межа температур, необхідна для того, щоб відобразити "гарячіші" чи "холодніші" пожежі відносно змін зображених на карті (рис. 11).

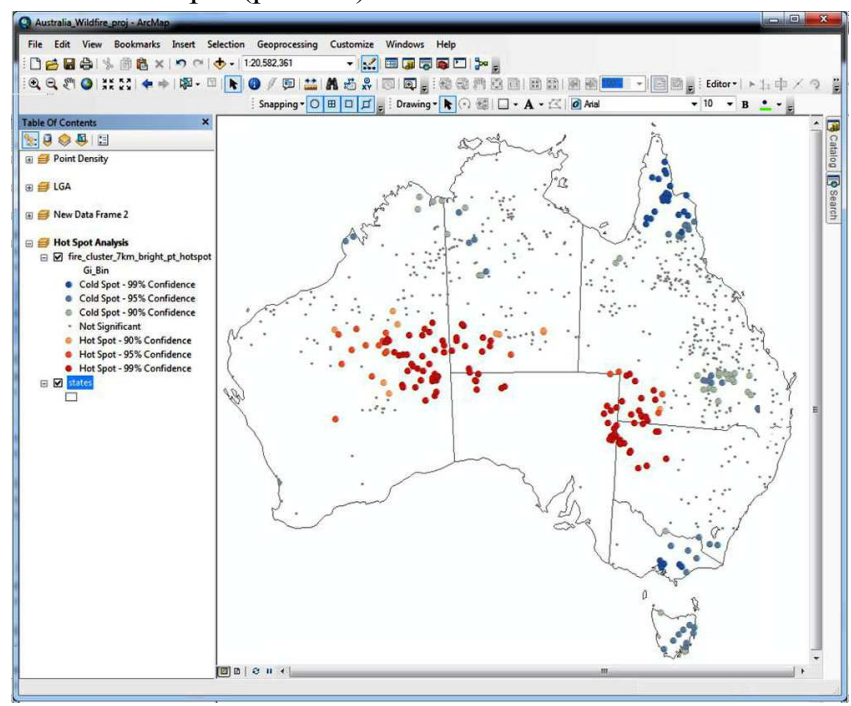

Рис. 11. Карта відображення "гарячих" i "холодних" точок у програмному середовищі ArcGIS

Два кластери значно вищих температур пожеж розташовуються в центрі континенту. На противагу цьому значно нижча температура пожеж кластера в Північному Квінсленді, Вікторії і Тасманії. Ця модель підтверджує гіпотезу про те, що пожежі з вищою температурою виникають у гарячому сухому центрі континенту, а пожежі в прохолодних середземноморських і тропічних регіонах мають нижчу температуру.

Проаналізувавши розподіл всіх пожеж (не тільки обраних), можемо зробити висновок, що між двома кластерами в січні 2013 р. не було пожеж, оскільки щось запобігало їх виникненню. Для цього може бути багато причин, включаючи погоду, заходи запобігання пожежами та відсутність горючого середовища. Якщо додати карту наземних екосистем світу (CONABIO) 3 ESRI Online [посилання] на нашу карту ("Add Data > Add Data From ESRI Online"), то можна побачити, що область без пожеж - пустеля, тоді як пожежі траплялися на пасовищах і в чагарниках.

Обговорення результатів дослідження. Цей метод $\epsilon$ продовженням досліджень, викладених в (Starodub et al., 2013; Starodub \& Havrys, 2015a, 2015b; Havrys, Steciuh \& Romanchuk, 2018; Zatserkovnyi, Tishayev \& Shyshenko, 2016; Havrys, 2018), і опирається на попередні розробки авторів.

Висновки. У цій роботі використано емпіричні дані (спостереження) для моделювання масштабів пожеж, природи виникнення вогню (температури) та впливу 
австралійських лісових пожеж у січні 2013 р. Подібний аналіз підходить для оцінки впливу подій після їх виникнення, він пояснює те, наскільки ймовірними є лісові пожежі в будь-якому місці. Для моделювання загального ризику необхідна інтеграція інформації про просторовий розподіл необхідних умов для лісових пожеж та джерело займання. Окрім цього, на основі цієї методики можна провести моніторинг та прогнозування наслідків пожеж в екосистемах та зменшити кількість збитків від цих надзвичайних ситуацій.

Унаслідок виконання роботи отримано такі результати:

1. Проаналізовано дані з інформаційної служби даних систем спостереження Землі HACA (EOSDIS) (NASA, 2019) і встановлено, що ці дані являють собою пікселі вище порогового значення температури, а не окремі пожежі;

2. Визначено походження і формат набору точкових даних лісових пожеж;

3. Проведено моделювання місць пожеж використовуючи точки пожеж;

4. Проведено моделювання зображення слідів пожеж з використанням історичних зображень Землі;

5. Проведено моделювання зміни температури вогню в різних точках;

6. Створено карти гарячих точок з використанням кластерного аналізу для дослідження просторової зміни температури вогню.

\section{Перелік використаних джерел}

ArcGIS Pro. (2019). Official website of the ArcGIS Pro. Retrieved from: http://pro.arcgis.com.

Google Earth. (2019). Official website of the Google Earth. Retrieved from: https://www.google.com.ua/intl/uk/earth/.
Havrys, A. P. (2018). Predicting emergencies using computer simulation data. Theory and practice of firefighting and emergency management, 158-159. Cherkasy. [In Ukrainian].

Havrys, A. P., Steciuh, I. V., \& Romanchuk, A. P. (2018). Rationale use of computer simulation in the emergencies risk management. Environmental safety as a basis for sustainable development of society. European experience and perspectives, 228-229. Lviv: LSU LS. [In Ukrainian].

NASA. (2019). Official website of the NASA. Retrieved from: https://worldview.earthdata.nasa.gov/.

Natural Earth. (2019). Official website of the Natural Earth. Retrieved from: http://www.naturalearthdata.com.

Recourses Agency. (2019). Official website of the State forest recourses agency. Retrieved from: http://dklg.kmu.gov.ua.

Starodub, Y. P., \& Havrys, A. P. (2015a). Use of HEC-GEORAS and HEC-RAS assistant software in territorial security projects. Project management and development of production, 1(53), 30-35. Luhansk. [In Ukrainian].

Starodub, Y. P., \& Havrys, A. P. (2015b). Increasing areas security project for the risk flooding territories of Ukraine. Central European Journal for Science and Research Stredoevropsky Vestnik pro vedu a vyzkum, 42-46. Praha.

Starodub, Y. P., Kuplovsky, B. E., Shelyuh, Y. E., \& Havrys, A. P. (2013). Fire areas localization using satellite data for seismic zones of Ukraine. Fire Safety, 23, 151-158. Lviv: LSU LS. [In Ukrainian].

Tasmania. (2019). Official data on the occurrence of wildfires in Tasmania, Australia for 2013. Retrieved from: http://www.tasmanianbushfires.com.au/tasmanian-bushfires-2013/.

Test center. (2019). Official website of the National space facilities control and test center. Retrieved from: http://spacecenter.gov.ua/dzz.

The Kilmore East Fire. (2010). Victorian Bushfires Royal Commission Report. Victorian Bushfires Royal Commission, Australia.

Zatserkovnyi, V. I., Tishayev, I. V., \& Shyshenko, O. I. (2016). Application of remote probe materials in tasks of forest monitoring and quantitative of vegetation. Science-intensive technologies, 1(29), 42-47. [In Ukrainian].

\section{A. P. Havrys, R. Ya. Moreniuk, I. M. Harasymiuk} Lviv State University of Life Safety, Lviv, Ukraine

\section{METHOD OF FIRE AREAS LOCALIZATION ON THE BASIS OF REMOTE SENSING DATA}

The authors analyse data of remote sensing of the Earth from the MODIS satellite, which displays the infrared temperature spectrum in the form of points (fires) in Australia. Fire points occur across most of the continent with the notable exception of much of Southern Australia and southern Western Australia. Many points appear to be grouped into globular clusters, but there may be some loose linear clustering occurring at a larger scale, for example parallel to the eastern coast of Queensland. This data is found to be pixels showing temperatures above the threshold and not individual fires. The simulation of fire areas using fire points with subsequent mapping of fire hazard sites was performed. A graphical relationship between the number of clusters and the distance between points in individual clusters were established and analyzed. The optimal distance to classify the cluster of points as a single fire and to create a landfill site using ArcGIS tools was determined. "Individual fires" are clusters of different numbers of points, with the number of points being determined by the following factors:1) individual fire size - larger fires have more points in the cluster; 2) the duration of each fire - longer fires are recorded by more satellite passes; 3 ) the frequency of satellite passes (more passes $=$ more points); 4) other factors, such as canopy cover, cloud cover and instrument failure. As the result we can conclude, that a simulation of the fires effects using historical images of the Earth, using the example of Australia in the period from December 2012 to December 2013 was performed. The simulation of the change in the ignition temperature at different points was made. The impact maps and fire hazard maps for local governments were developed and analyzed on the example of Australian territories. Hotspot maps using cluster analysis to determine the spatial variation of the ignition temperature at these points were created. The use of current method of fire areas localization together with historical data on fires of the selected region for the prediction and analysis the probability of fires occurrence in the individual investigated territories was proposed.

Keywords: computer simulation; fire; satellite data; wildfire; cluster analysis. 